\title{
Distribution and Habitat Selection by Muntjac and Other Species of Deer in a Coniferous Forest
}

\author{
Norma G. CHAPMAN, Kathie CLAYDON, Mick CLAYDON \\ \& Stephen HARRIS ${ }^{1}$
}

\begin{abstract}
Chapman N. G., Claydon K., Claydon M. \& Harris S., 1985: Distribution and habitat selection by muntjac and other species of deer in a coniferous forest. Acta theriol., 30, 18: 287-303 [With 2 Tables \& 5 Figs.]

In the King's Forest in Suffolk, England, an area of 2360 ha of mainly coniferous commercial woodland, the distributions of four species of deer were recorded on a presence/absence basis in each of 228 compartments. These distributions were compared with simple habitat and other variables describing the compartments. Muntjac Muntiacus reevesi (Ogilby, 1839) were found to be selecting areas with a variety of vegetation types, particularly ground vegetation; range of bush species, presence of bramble and raspberry, and percentage of mature nut producing broad-leaf trees were the variables showing the most significant correlations with muntjac presence. Roe deer were found throughout nearly the whole Forest, and so on a simple presencel absence basis no conclusions on habitat selection could be made. Fallow deer were selecting the most mature compartments in the Forest. particularly those with a high percentage of Scots pine, and were avoiding areas with a high percentage of Corsican pine. Red deer were also avoiding compartments with Corsican pine, and were selecting those with a high percentage of Scots pine; they were also avoiding areas with a diversity of tree types. Discriminant analysis, based on the most significant habitat variables examined, proved to be a useful method for explaining the current distribution of muntjac in the King's Forest.

[Larkmead, Barton Mills, Bury St. Edmunds, Suffolk, U. K.; 109 Tithelands, Harlow, Essex, U. K. and ${ }^{1}$ Department of Zoology, University of Bristol, Woodland Road, Bristol. U. K.]
\end{abstract}

\section{INTRODUCTION}

Since their introduction to Woburn at the beginning of this century, feral muntjac Muntiacus reevesi (Ogilby, 1839) have spread widely throughout much of southern England. Despite their wide distribution, little is known about the ecology of feral muntjac. They are most numerous in parts of central southern England (Corbet \& Southern, 1977), where they are to be found in small scattered deciduous or mixed woodlands. Derelict areas such as as scrubland, overgrown gardens, neglected orchards and overgrown pits in arable fields are also used (Soper, 1969; Clark, 1981). Based on observations in areas where muntjac are numerous, Dansie (1977) concluded that dense cover is "obligatory for successful

\footnotetext{
1 Address for correspondence and reprint requests.
} 
establishment" and Soper (1969) believed that "deciduous woods are preferred, as plantations of coniferous trees rarely allow the growth of sufficient low cover". However, with their continued spread, muntjac are now becoming established in commercial woodlands that are either largely or completely coniferous. One such woodland is the King's Forest in Suffolk, where a study is being undertaken by the authors to examine the behaviour of muntjac in commercial coniferous woodland.

The present paper aims to describe the distribution and habitat selection by muntjac in a mainly coniferous forest, and to compare these with the other species of deer also living there,

\subsection{The Study Area}

The King's Forest is in the Brecklands in north-west Suffolk; it covers an area of $2360 \mathrm{ha}$ and is a mainly coniferous forest owned by the Forestry Commission. Administratively it forms part of Thetford Forest. The King's Forest lies to the south of the main forest and is surrounded on all sides by heathland, rough pasture, or cultivated land used for growing sugar beet, barley and carrots.

The Forestry Commission purchased the land which comprises the present King's Forest in 1934, and tree planting has continued until the present day. Some recent plantings followed the felling of the first crop of timber. Scots pine (Pinus silvestris) was the main species planted up to the 1940 s, but higher yields resulted in Corsican pine (Pinus nigra) being used in preference thereafter, and very little Scots pine has been planted in the last 20 years. Small areas were planted with larch (Larix decidua), Western hemlock (Tsuga heterophylla) and Douglas fir (Pseudotsuga taxifolia). Other conifer crops were infrequent.

The present King's Forest is divided into 228 mostly square or rectangular compartments, ranging in size from four to 20 ha $(\bar{x}=10.3$ ha). Most compartments consisted of several different plantings or sub-compartments. Within each compartment the sub-compartments usually consisted of trees of different ages or species or both, but within each sub-compartment the trees were of a uniform age, and usually of a single species. In addition to the commercial crops, many of the old coverts and shelter belts were retained as sub-compartments in the Forest, so that there were several conifer and broad-leaf plantings over 120 years old. The main broadleaf species were oak (Quercus sp.), beech (Fagus sylvatica), sweet chestnut (Castanea sativa), elms (Ulmus spp.), ash (Fraxinus excetsior) and sycamore (Acer pseudoplatanus). The Forestry Commission has also planted strips of broadleaf trees, mainly birch (Betula sp.), beech and oak, and along many of the roadside verges were single rows of mature beech, sycamore and horse chestnut (Aesculus hippocastanum). The Forest therefore consisted of a complex mosaic of diverse sub-compartments. Of the 228 compartments, 20 consisted of a single planting, 70 had two sub-compartments, 64 had three, 47 had four, 14 had five, eight had six, seven had four, and one had ten different sub-compartments.

The compartments and their sub-compartments, together with the year of planting and main tree species for each sub-compartment, were recorded on a plantings map scale $1: 10,000$, which had been compiled by the Forestry Commission; this map was used as a basis for the vegetation survey. 


\subsection{History of the Deer in the King's Forest}

The distribution of deer in Suffolk has been described by Cham (1984). Four species were present in the King's Forest, and a brief synopsis of the history of each species follows.

\subsubsection{Muntjac Muntiacus reevesi (Ogilby, 1839)}

The first records of muntjac within the King's Forest date from 1963 (G. Marshall, pers. comm.), but previously there had been a few records: from the area to the north. It is unlikely that the muntjac were established in the King's Forest prior to 1963 . The 1962 Forestry Commission Mammal/Bird/Damage Return recorded muntjac as absent. Muntjac are said to suffer heavy mortality in hard winters, such as those in 1946-47 (Teylor, 1948) and 1962-63 (Dansie, 1983). If muntjac had been present in the King's Forest during the prolonged and severe winter of 1962-63 it is probable that some would have been found dead. Records by Forestry Conmission personnel refer to 14 dead roe being found that winter, but no dead muntjac. Following the first record in 1963, muntjac sightings became increasingly common in the later part of the 1960s and throughout the 1970s. There were no estimates of the number of muntjac present in the Forest during the survey period.

\subsubsection{Roe deer Capreolus capreolus (Linnaeus, 1758)}

The roe was the most numerous and widely distributed deer in Thetford Forest and on the surrounding privately-owned land. This population originated from six pairs introduced from Germany in 1884 to an area between Brandon and Thetford. From there the roe dispersed in various directions, including southwards to the area of the present King's Forest, where they were recorded early this century (Noble, 1903). When the King's Forest was established in the 1930 s, the young plantations provided adcitional suitable cover for the roe, and the species quickly became established. The 1983 Forestry Commission census estimated that therewere 68 bucks and 125 does in the King's Forest.

\subsubsection{Fallow deer Dama dama (Linnaeus, 1758)}

The fallow deer in the King's Forest originated from one or possibly two former park herds which escaped earlier this century. Their early hissory in the King's Forest is unknown; they were certainly present in 1962 (Forestry Commission Mammal/Bird/Damage Return) and by 1970 were well established though not numerous (A. Reeman, pers. comm.). 
The 1983 Forestry Commission census estimated that there were 17 bucks and 38 does in the King's Forest.

\subsubsection{Red deer Cervus elaphus (Linnaeus, 1758)}

The feral population of red deer in the Thetford Forest area is descended from carted deer which the Norwich Staghounds failed to re-take at the end of a day's hunt; this pack of staghounds hunted in Norfolk until 1963 (Whitehead, 1980). The red deer in the King's Forest were not permanently resident, but were thought to be vagrant animals which originated from the main population living in other forests in the Thetford area. This population of red deer has been declining in recent years; the 1983 Forestry Commission census estimated the total number of red deer in the Thetford area to be 117; most sightings in the King's Forest were of solitary animals or small groups.

\section{METHODS}

\subsection{Deer Survey}

Each of the 228 compartments was visited on various occasions during the period May 1979 to April 1982, with the majority of the visits being made during the winter and spring months when there was less ground cover to obscure observations. Each compartment was slowly walked round, and often through as well, the deer being driven towards observers on the rides. In addition casual records were collected by Forestry Commission personnel and others. When a deer was sighted on a ride between two compartments it was considered to be crossing from one to the other, and recorded for both. Only sightings of deer were included: faecal pellets and footprints were disregarded to avoid any possibility of misidentification between similar species. The confusion inherent with several different observers trying to identify the faeces of different species of deer, particularly differentiating those of muntjac and roe, precluded in this study the use of pelletgroup counts to quantify the levels of activity in different habitat types.

\subsection{Vegetation Survey}

The vegetation survey was undertaken in October and November 1983. For uniformity only one person (S. H.) was involved with the field work. Every subcompartment of all 228 compartments was visited, checked against the Forestry Commission plantings map, and the vegetation for each individual sub-compartment recorded. Where the compartment had an adjacent feature not marked on the plantings map, but which may have been important to the deer, it was treated as an additional sub-compartment and included in the vegetation survey for that compartment. On this basis, areas of rough grassland, scrub and the rows of mature broad-leaf trees that lined most of the roads through the Forest were included.

During the vegetation survey, each sub-compartment was traversed several 
times. Broad vegetational cover scales such as Domin and Braun-Blanquet (Shimwell, 1971; Goldsmith \& Harrison, 1976) were not suitable for the present analysis; instead the following data were recorded:

(1) The relative importance of each tree species was assessed by counting sample areas within the sub-compartment; the age of the trees was extracted from the plantings map.

(2) The average spacing of the trees was assigned to one of the following categories: $0-1.5 \mathrm{~m}, 1.5-3 \mathrm{~m}, 3-4.5 \mathrm{~m}$, and over $4.5 \mathrm{~m}$. In addition, for the first three categories, where there were gaps in the plantings (glades), the planting was also recorded as being irregular.

(3) Ground cover from fallen trees and branches was recorded on a one tol five scale, where one was very sparse, two was just enough to provide cover for a muntjac, up to five, which was difficult for a person to penetrate.

(4) Ground cover from vegetation was assessed as $\%$ grass, $\%$ herb, $\%$ bracken (Pteridium aquilinum), $\%$ bush and $\%$ open ground. Herb cover was taken to include all broad-leaf plants which were on average between 25 and $100 \mathrm{~cm}$ in height. On this basis brambles (Rubus fruticosus agg.) and raspberry (Rubus idaeus) were included as contributing to the herb cover, since they were normally less than $70 \mathrm{cms}$ in height under the trees, whilst climbing species such as ivy (Hedera helix) and clematis (Clematis vitalba) were included as contributing to the bush cover. In addition, for the grasses and bushes an index of the number of species was assessed on a one to five scale, i.e. $1=$ one species, $2=$ two to three species, $3=$ four to five species, $4=\operatorname{six}$ to seven species, $5=$ eight or more species. For the herbs, these same categories were assessed using the number of families rather than the number of species. This index was based on all the herbs present, including those less than $25 \mathrm{cms}$ high.

(5) The presence of arable fields, pasture land or heath land adjoining the compartment was recorded.

(6) The total area for each compartment was given on the plantings map; this map was copied and enlarged to a scale of approximately $1: 5000$, and the area of each sub-compartment and percentage of the total compartment calculated, from the enlarged map using a Summagraphics "Bit Pad One" digitizing tablet linked to a Research Machines $380 \mathrm{Z}$ microcomputer.

\subsection{Statistical Procedures}

To compare the distribution of the deer in the Forest, the habitat data for the sub-compartments in each compartment were averaged, with each sub-compartment weighted according to its size. Correlation coefficients were calculated comparing these averaged data with the presence/absence of all four species of deer.

To examine the habitat variables most significant in explaining the current distribution of the deer in the Forest, discriminant analysis was used to predict species presence/absence, with discriminant functions calculated from selected habitat variables. Successive trials of suitable combinations of habitat variables were undertaken. The methodology is given in Cooley \& Lohnes (1971), Marriott (1974) and Green (1979). The use of discriminant analysis in ecology has recently been reviewed by Williams (1983), who also discussed the assumptions necessary when applying the technique to ecological data. 


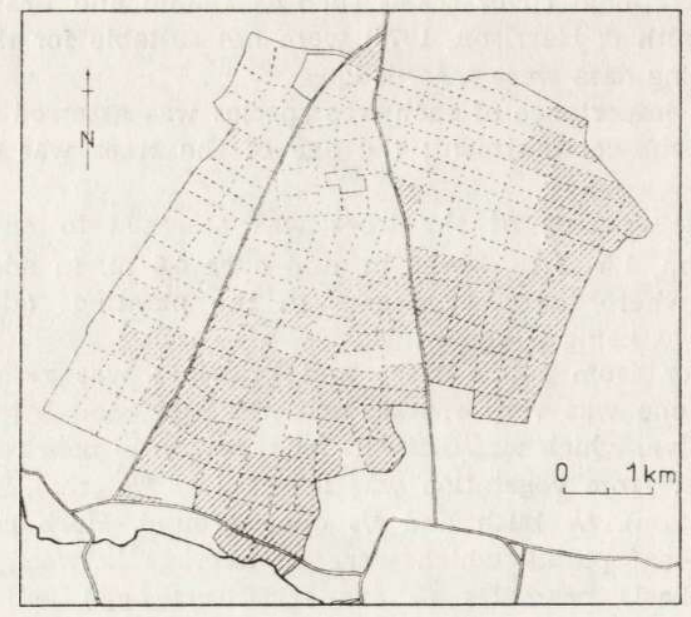

Fig. 1. Distribution of muntjac in the King's Forest. Hatching denotes those compartments in which deer were recorded between May 1979 and April 1982.

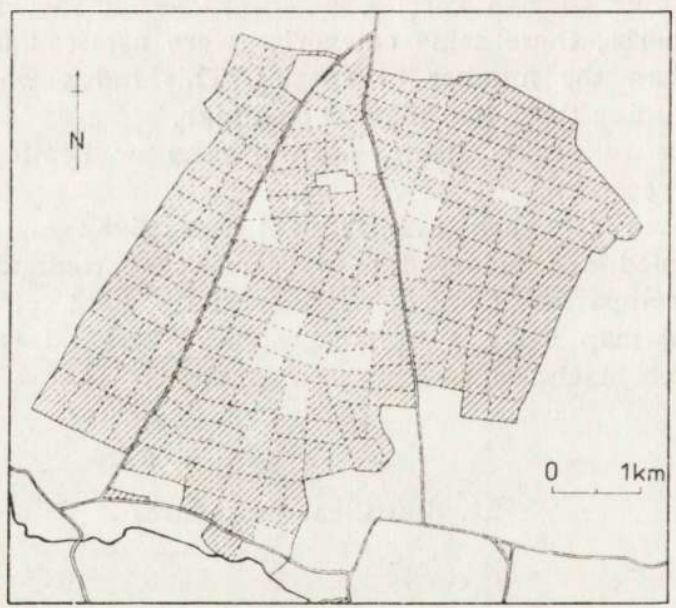

Fig. 2. Distribution of roe deer in the King's Forest. Hatching denotes those compartments in which deer were recorded between May 1979 and April 1982.

\section{RESULTS}

Of the 228 compartments, muntjac were recorded in 112 , roe in 208 , fallow in 79 , and red deer in 25 . No deer were recorded in eight compartments, one species only in 75 compartments, two species in 93 , three 


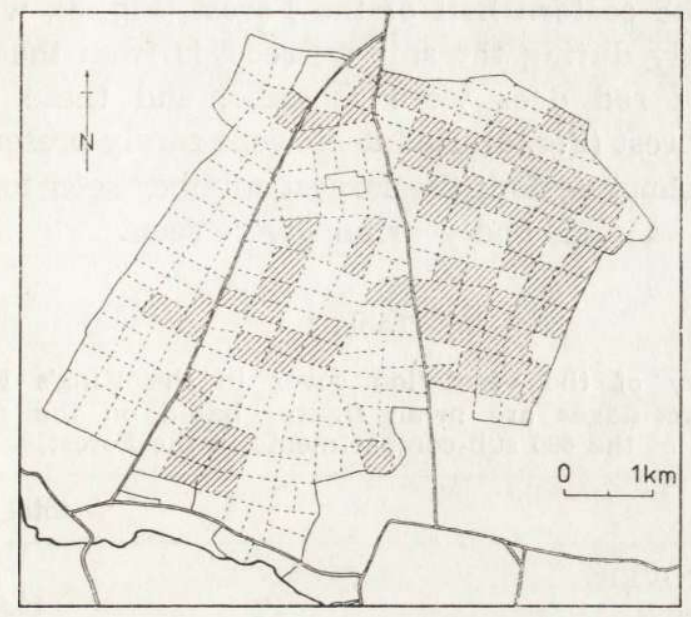

Fig. 3. Distribution of fallow deer in the King's Forest. Hatching denotes those compartments in which deer were recorded between May 1979 and April 1982.

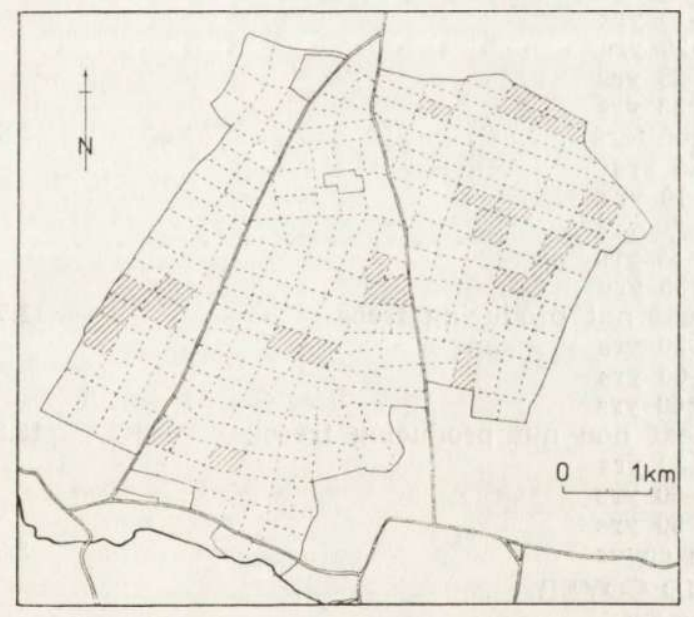

Fig. 4. Distribution of red deer in the King's Forest. Hatching denotes those compartments in which deer were recorded between May 1979 and April 1982.

species in 45 , and all four species in seven compartments. Most sightings of muntjac were in the southern and eastern parts of the Forest (Fig. 1), whilst sightings to the north were few. In the south and east of the Forest, muntjac were seen frequently and at all times of the year. Roe deer were distributed throughout the Forest (Fig. 2). Fallow deer were 
mainly seen on the eastern half of the Forest (Fig. 3), where they were recorded frequently during the survey; records from the west side were rare. Sightings of red deer were sporadic, and these were scattered throughout the Forest (Fig. 4). Red deer were rarely present in the Forest for more than a short period; the largest number seen together was ten, and stags as well as hinds and yearlings were seen.

\section{Table 1}

Summary of the vegetation cover in the King's Forest. The percentages are mean figures based on the survey of the 696 sub-compartments in the Forest.

\begin{tabular}{|c|c|c|}
\hline & $\%$ total & cover \\
\hline \multicolumn{3}{|l|}{ TREE COVER } \\
\hline Scots pine & 19.5 & \\
\hline $5-10$ yrs & & 0 \\
\hline $10-20$ yrs & & 0.8 \\
\hline $20-35$ yrs & & 10.9 \\
\hline $\begin{aligned}>35 \text { yrs } \\
\text { Corsican pine }\end{aligned}$ & & 7.8 \\
\hline $\begin{array}{l}\text { Corsican pine } \\
<5 \text { yrs }\end{array}$ & 45.5 & \\
\hline$<5$ yrs & & 2.0 \\
\hline \multicolumn{3}{|l|}{$5-10$ yrs } \\
\hline $10-20$ yrs & & 9.4 \\
\hline $20-35$ yrs & & 16.8 \\
\hline$>35$ yrs & & 14.0 \\
\hline \multicolumn{3}{|l|}{ Other conifers } \\
\hline$<5$ yrs & & 0 \\
\hline $5-10$ yrs & & 0 \\
\hline $10-20$ yrs & & 0.7 \\
\hline $20-35$ yrs & & 1.8 \\
\hline$>35$ yrs & & 1.8 \\
\hline \multicolumn{3}{|l|}{ Broad-leaf nut producing trees } \\
\hline$<30$ yrs & & 0.8 \\
\hline $30-60$ yrs & & 3.7 \\
\hline$>60$ yrs & & 7.2 \\
\hline \multicolumn{3}{|l|}{$\begin{array}{c}\text { Broad-leaf non nut producing trees } \\
<30 \text { yrs }\end{array}$} \\
\hline$<30$ yrs & & 6.6 \\
\hline $30-60$ yrs & & 7.0 \\
\hline$>60$ yrs & & 1.7 \\
\hline No tree cover & 3.8 & \\
\hline \multicolumn{3}{|l|}{ GROUND COVER } \\
\hline Grass cover & & 42.2 \\
\hline Herb cover & & 13.6 \\
\hline Bracken cover & & 2.7 \\
\hline Bush cover & & 5.0 \\
\hline Bare ground & & 36.5 \\
\hline
\end{tabular}

To examine the spatial relationships in the distribution of the four species of deer, a standard normal deviate was used (Ebdon, 1977). Muntjac $(z=-13.41)$, fallow $(z=-5.47)$ and red deer $(z=-3.19)$ were all significantly clustered at the $0.1 \%$ level, using a one-tailed negative 
Table 2

Significant correlation coefficients of deer presence against habitat variables for the 228 compartments in the King's Forest.

$r=0.130$ at $5 \%, 0.170$ at $1 \%$ and 0.216 at $0.1 \%$. Correlation coefficients not significant at the $5 \%$ level are not given.

\begin{tabular}{|c|c|c|c|}
\hline & Muntjac & Fallow & Red \\
\hline \multicolumn{4}{|l|}{ Area of compartment } \\
\hline Area of largest sub-compartment & -.163 & & \\
\hline Number of sub-compartments & .146 & & -.165 \\
\hline $\begin{array}{l}\text { Shannon-Weiner index of diversity of } \\
\text { sub-compartments }\end{array}$ & & & \\
\hline Peripheral compartment & & -.154 & \\
\hline \multicolumn{4}{|l|}{ Average age of trees } \\
\hline Age of trees in largest sub-compartment & & .232 & \\
\hline Tree spacing & .144 & & \\
\hline Shannon-Weiner index of tree diversity & .290 & & -.203 \\
\hline \multicolumn{4}{|l|}{$\begin{array}{l}\text { Shannon-Weiner index of diversity } \\
\text { of trees plus glades }\end{array}$} \\
\hline $\begin{array}{l}\% \text { Scots pine } \\
\% \text { Corsican pine }\end{array}$ & & $\begin{array}{r}.159 \\
-.165\end{array}$ & .131 \\
\hline$\%$ other conifers & .182 & & \\
\hline$\%$ broad-leaf nut producing trees & .220 & & \\
\hline Log. $\%$ broad-leaf nut producing trees $\times$ age & .323 & & \\
\hline Log. $\%$ broad-leaf nut producing trees $>40$ yrs & .305 & & -.135 \\
\hline \multicolumn{4}{|l|}{$\%$ broad-leaf non nut producing trees } \\
\hline \multicolumn{4}{|l|}{$\%$ total area glades } \\
\hline No. tree species & .316 & & -.173 \\
\hline \multirow{2}{*}{\multicolumn{4}{|c|}{ Presence Scots pine }} \\
\hline & & & \\
\hline Presence Corsican pine & & & -.158 \\
\hline No. conifer species excluding Scots and Corsican & 208 & & \\
\hline No. broad-leaf tree species & .302 & & -.143 \\
\hline No. broad-leaf nut producing tree species & .302 & & \\
\hline & .243 & & -.156 \\
\hline Shannon-Weiner index of ground & .217 & & \\
\hline Shannon-Weiner index of diversity & & & \\
\hline $\begin{array}{l}\text { of ground vegetation plus bare ground } \\
\text { Cover from fallen trees and branches }\end{array}$ & .195 & .131 & \\
\hline \multicolumn{4}{|l|}{$\%$ grass cover } \\
\hline$\%$ herb cover & .185 & & \\
\hline $\begin{array}{l}\% \text { bracken cover } \\
\% \text { bush cover }\end{array}$ & & & \\
\hline $\begin{array}{l}\% \text { bush cover } \\
\% \text { bare ground }\end{array}$ & & .176 & \\
\hline \multicolumn{4}{|l|}{ Index of no. grass species } \\
\hline Index of no. herb families & .203 & & \\
\hline Index of no herb families $\times \%$ herb cover & .190 & & \\
\hline Index of no. bush species & .484 & & \\
\hline $\begin{array}{l}\text { Index of no. bush species } \times \% \text { bush cover } \\
\text { Index of no, bush species } \times \% \text { ground }\end{array}$ & .214 & & \\
\hline $\begin{array}{l}\text { Index of no. bush species } \times \% \text { ground } \\
\text { vegetation cover }\end{array}$ & .329 & & \\
\hline Presence of bramble & .231 & .131 & \\
\hline Presence of raspberry & .348 & & \\
\hline Presence of bramble and raspberry & .351 & & \\
\hline
\end{tabular}


test. For roe $z=-1.03$; this was not significantly different from random, using a two-tailed test. There were no significant correlations in the distributions of the four species of deer.

A summary of the vegetation cover in the King's Forest is given in Table 1. Conifers formed $69.2 \%$ of the tree cover, broad-leaf trees formed $27.0 \%$ and $3.8 \%$ of the Forest (excluding the rides) lacked tree cover. The distributions of the four species of deer were compared with 43 variables describing the vegetation and other features of the $228 \mathrm{com}$ partments (Table 2). Muntjac distribution showed significant correlations with compartments that had a high level of diversity; compartments divided into a large number of sub-compartments and containing a diversity of tree types, especially those that contained mature broad-leaf

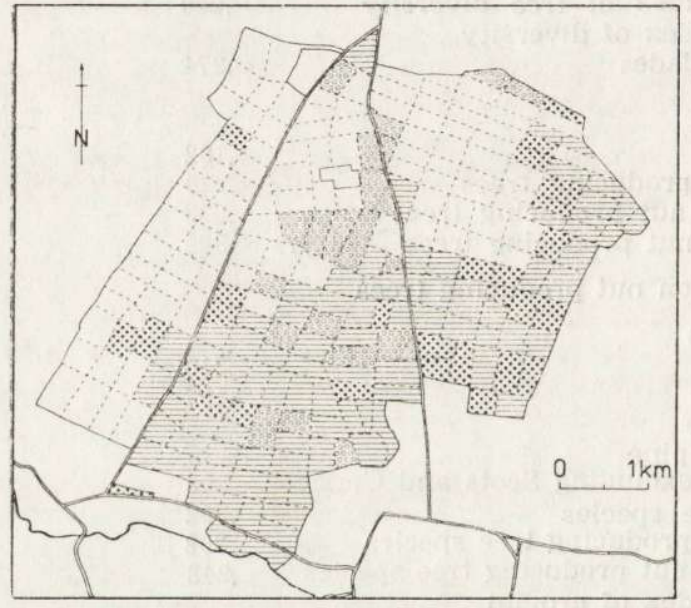

Fig. 5. Performance of the discriminant function based on range of bush species, presence of raspberry, Shannon-Weiner index of tree diversity and $\log$. $(1+\%$ broad-leaf nut producing trees $X$ age) in predicting muntjac presence/absence in each compartment. No shading denotes absence correctly predicted, horizontal lines presence correctly predicted. Open circles denote absence incorrectly predicted, closed circles denote presence incorrectly predicted.

nut producing trees, were particularly selected. At ground level diversity of vegetation rather than percent ground cover was important. A range of bush species was the most significant of the variables examined, with presence of bramble and raspberry and a range of herb species all also showing significant correlations with the presence of muntjac.

$\mathrm{R}$ o e deer had been recorded in nearly every compartment, and so 
in this sort of analysis there were no significant correlations with any of the habitat variables.

Fallow deer were selecting mature compartments, preferring a high percentage Scots pines in the tree cover and avoiding areas with a high percentage Corsican pines, selecting areas with a diversity of ground vegetation interspersed with areas of bare ground, and were correlated with the presence of bramble and a high percentage bush cover. Red deer were also significantly correlated with the percentage Scots pines in the tree cover; all other significant correlations were negative. They were avoiding compartments divided into a large number of subcompartments, were avoiding compartments with a high diversity of trees present, particularly if there was a diversity of trees interspersed with glades, and were avoiding areas containing broad-leaf trees.

To examine the current distribution of $\mathrm{muntjac}$ in the Forest, discriminant functions were calculated from the most significant habitat variables in Table 2. Range of bush species, the most significant variable, was in itself a successful indicator of the presence of muntjac, and with a discriminant model based on this one variable $71.5 \%$ of compartments were correctly classified, with predicting absence $(73.3 \%)$ slightly more successful than predicting presence $\left(69.6^{0} \%\right.$ ) (Mahalanobis distance 1.100 , Wilks's $\lambda$ statistic $\left.=0.769, F_{(1,227)}=67.99\right)$. However, the most successful model was with a discriminant calculated as:

$$
\Delta=2.40-0.736 x_{1}-1.473 x_{2}-0.405 x_{3}-0.308 x_{4}
$$

where $x_{1}=$ range of bush species, $x_{2}=$ presence of raspberry, $x_{3}=$ Shannon-Weiner index of tree diversity and $x_{4}=\log$. $(1+\%$ broad-leaf nut producing trees $\times$ age). Muntjac were estimated to be present if $\Delta<0$ and absent if $\Delta>0$. With this model $78.9 \%$ of the compartments were correctly classified (Fig. 5), again with a slightly higher success rate in predicting absence $(82.8 \%)$ than predicting presence $\left(75.0^{\%} \%\right)$. Of the 28 compartments in which the model suggests muntjac should not be present, but from which muntjac were recorded, 23 were adjacent to compartments correctly assigned by this model. Possible reasons for this are discussed below. With this model there was a good separation of the population means (Mahalanobis distance 1.289, Wilks's $\lambda$ statistic 0.717 , $\left.F_{(4224)}=22.07\right)$.

For fallow deer, the discriminant analysis was not a successful approach to analysing their distribution in the King's Forest. The best model, based on all the significant habitat variables in Table 2, predicted that fallow should be more widely distributed; possible reasons for this disparity in observed and predicted results are discussed below. Since red deer were only sporadically present in the Forest, no detailed analysis of their distribution was undertaken 


\section{DISCUSSION}

Deer are notoriously difficult to observe or census in woodland habitats; the problems involved and the techniques utilised are summarised by Mitchell, Staines \& Welch (1977). In the present study observations were used to determine the presence/absence of four species of deer in relatively small woodland compartments. It was possible that this technique would not be equally suited to all four species. For instance, Hofmann (1982) classified ruminants into three distinct feeding types, based on morphological and functional characteristics of the stomach. He suggested that roe deer will have more feeding cycles each day than red deer, and so in a survey such as ours, based solely on sightings, red deer could have a reduced chance of being recorded. If there was such a bias, the distribution shown in Fig. 4 would reflect the number of visits made to each compartment. However, there was no significant difference in the number of visits to compartments from which red deer were recorded $(\bar{x}=10.6 \pm 9.5)$ compared to those in which they were not recorded $(\bar{x}=9.8 \pm 10.2) ; t=0.41$ for 226 d.f.

Besides our regular visits to the compartments, forest workers responsible for silviculture and deer culling operations assisted with the survey and their sightings over the same three year period supplemented our records. Their information confirmed our data on the distribution of the four species of deer, and it is felt, therefore, that the results convey an accurate indication of the compartments most frequently used (presence) or rarely visited (absence) by each species of deer. However, the data were not suitable for a more detailed analysis. For instance, it was not feasible to use the number of sightings per species per visit or some similar method to quantify the relative numbers of deer in each compartment, since it would be impossible to equate ease of visibility in different age stands of trees. Despite these limitations with the survey data, discriminant analysis has proved useful in explaining the distribution and habitat selection by muntjac in the King's Forest.

In its native habitat in south-east Asia, Reeves' muntjac inhabits the scrub vegetation between 200 and $400 \mathrm{~m}$ in the hills and low mountains of much of tropical and subtropical China (H. Lu, pers comm.). Whitehead (1972) described the native habitat as woodland, although he stated that muntjac do not seem to differentiate much between teak (Tectona grandis) and other types of forest, provided there is plenty of undergrowth to provide food and shelter. In Britain the most usual habitat for muntjac has been described as deciduous or mixed woodland (Dansie, 1977), and subjective impressions by a number of authors have suggested that dense cover is a prime requirement for successful colonisation (Soper, 
1969; Chaplin, 1977; Dansie, 1983). Clark (1981) found that young conifer plantations and woodland with dense ground cover were favoured, although other habitats were utilised, providing that overgrown or neglected cover was present.

The present study has indicated that in the King's Forest variety of ground vegetation rather than density of ground cover is important. Of all the percentage ground cover categories, only percent herb cover correlated weakly with muntjac distribution. Also, there was no indication that muntjac were avoiding areas with a high percentage of open ground, nor were they particularly selecting areas with dense cover from fallen branches and trees.

It is possible that similar factors may be important for muntjac in other parts of the country. Although a range of tree types was present in the King's Forest, the ground vegetation was comparatively species poor, and so the largest indices of species abundance used in this study were attained with relatively low numbers of species. It seems probable that although parts of the King's Forest were sufficiently suitable for muntjac to be well established as a resident and increasing population, it was not "optimum" muntjac habitat. Subjective impressions of population density based on field signs and number of observations suggested that fewer muntjac were present than in other English woodlands with a greater variety of ground vegetation. For instance, Bernwood Forest on the Buckinghamshire/Oxfordshire border consists of 260 ha of very mixed woodland; the whole Forest comprises a great diversity of vegetation at all levels, and the grass rides support a large number of species of herbs and self-propagated shrubs, trees and climbers. Signs of muntjac were abundant in 1983 (N. G. C., pers. obs.) and signtuigs by forestry Commission personnel were numerous ( 1 . K. Braadury, pers. comm.). Muntjac are believed to have arrived there in about 1yoz, so although muntjac were first sighted at about the same time in botn Bernwood and the King's Forest, at the former their population density is almost certainly much higher. Similar observations have been made in some of the woods within the Forest of Arden in Warwickshire, such as Wappenbury and Weston. These have been colonised by muntjac since the 1950s (Pickvance \& Chard, 1960). These woods also nave a great diversity of planted trees, thickets, neglected coppice and ground tlora, and again subjective impressions in 1983 (N. G. C., pers, obs.) suggested that muntjac were much more numerous than in the King's rorest.

In the discriminant analysis, 28 compartments from which muntjac had been recorded were incorrectly classified. The majority (23) of these compartments were adjacent to compartments correctly classified as containing muntjac. Radio-tracking studies by the authors in the south- 
east corner of the Forest have suggested that the compartments in that area incorrectly classified in the discriminant analysis were less heavily used by muntjac, and that these compartments were the ones into which juvenile and sub-adult animals moved from more suitable areas. Similar observations have been made on other species of deer, and Loudon (1983) has described the effects of habitat on the population performance in roe deer.

Chapman \& Chapman (1980) reviewed the world distribution of fallow deer, and discussed in broad terms the vegetation types from which fallow deer had been recorded. They noted that in England deciduous broad-leaf forest is regarded as the typical habitat, although fallow will take advantage of whatever habitats are available. Yet in a mosaic environment such as the King's Forest, it was not the areas of deciduous trees that were selected, but areas of mature conifers, and particularly areas with a large proportion of Scots pine. With the fallow, the most significant correlation was with the age of the trees in the largest subcompartment. Of the 79 compartments from which fallow were recorded, two consisted of old deciduous trees. For the remaining 77 largely or exclusively coniferous compartments, the average age of the trees in the largest sub-compartment was 35.3 years $(S D \pm 9.1)$. This preference for older plantings probably explains why the fallow were first recorded in the Forest in the $1960 \mathrm{~s}$, when the first plantings attained this age, although fallow had been present in the area around the Forest for some time. It is only in recent years, as more of the Forest compartments reach the end of their first rotation, that fallow have become relatively common. Batcheler (1960) made similar observations in Drummond Hill Forest in Scotland. The discriminant analysis suggests that fallow deer should be more widely distributed in the King's Forest. From our survey it would appear that they are becoming more common in the mature compartments, and that as a greater proportion of the Forest approaches the end of its first rotation fallow are likely to become more widely distributed within the Forest.

Both fallow and red deer were avoiding those parts of the King's Forest in which Corsican pine was most common, and were preferring areas with Scots pine. In a study of the food of fallow deer in the New Forest, Jackson (1974) found that whilst Scots pine was eaten Corsican was rarely taken, although it was present in the area; browse from conifers formed up to $17 \%$ of the diet of New Forest fallow.

Mitchell, Staines \& Welch (1977) reviewed the species of tree browsed by red deer; Scots pine was eaten but was not a highly preferred species. In continental Europe, where deep snow cover is a conspicuous feature for much of the winter, bark from mature Scots pine forms an important 
part of the diet for red deer (e.g. Szukiel, 1981). In the Brecklands, however, snow cover is rare, and there is no evidence of bark stripping by red deer. In a study in another part of Thetford Forest, Hearney \& Jennings (1983) found that the major summer food of red deer was the browse of broad-leaf trees and shrubs, together with grasses and grasslike plants. In winter the main foods were ivy, bramble and a variety of grasses, with small amounts of conifer browse. Yet in the King's Forest, the distribution of red deer was not found to correlate with any variables describing the percentage or diversity of grass or bush cover, and was negatively correlated with the number of broad-leaf tree species.

Of the 24 largely coniferous compartments in which red deer were recorded, the average age of the trees in the largest sub-compartment was 33.3 years $(\mathrm{SD} \pm 8.6 \mathrm{yrs})$. Similar aged compartments were selected by the red deer in other areas of Thetford Forest; most consisted of Scots pine, or Scots pine mixed with other conifers or broad-leaf trees, planted in the $1920 \mathrm{~s}$ and $1930 \mathrm{~s}$. Unlike the King's Forest, however, these older compartments had a dense ground cover of bracken or bramble. Since the King's had few such compartments, it may be that the Forest is relatively unsuitable for red deer.

Acknowledgements: Studies on the deer of the King's Forest were initiated by the late Donald Chapman. The authors would like to acknowledge their gratitude to Donald, who encouraged and stimulated their interest in deer and did some of the field work for this paper. We are indebted to the Forestry Commission for their permission to carry out this study, and to $\mathrm{Mr}$ A. Reeman, the King's Forest Ranger, for his help. B. Barton, A. Burton, G. \& G. Blamey, J. Caldwell, S. Cham, B. Eastcott, A. Gudgion, J. Harding, M. Lovell, A. \& M. Rivett, C. \& P. Skinner and T. Morton assisted with the deer survey. We are grateful to Dr J. M. V. Rayner for his help with the analysis, and Drs B. Mitchell, B. Staines and D. Welch provided helpful comments on an early draft of this paper.

\section{REFERENCES}

1. Batcheler C. L., 1960: A study of the relations between roe, red and fallow deer, with special reference to Drummond Hill Forest, Scotland. J. Anim. Ecol., 29: 375-384.

2. Cham S. A., 1984: A survey of the distribution of deer in Suffolk. Trans. Suffolk Nat. Soc., 20: 10-24.

3. Chapman N. G. \& Chapman D. I., 1980: The distribution of fallow deer: a worldwide review. Mammal Rev., 10: 61-138.

4. Chaplin R., 1977: Wild deer in Britain. Jarrold \& Sons: 1-32. Norwich.

5. Clark M., 1981: Mammal watching. Severn House: 1-176. London.

6. Cooley W. W. \& Lohnes P. R., 1971: Multivariate data analysis. John Wiley \& Sons: 1-364. New York.

7. Corbet G. B. \& Southern H. N., 1977: The handbook of British mammals. Blackwell Sci. Publ.: 1-520. Oxford.

8. Dansie O., 1977; Muntjac Muntiacus reevesi. [In: "The handbook of British 
mammals", Corbet G. B. \& Southern H. N., Eds.]. Blackwell Sci. Publ.: 447-451. Oxford.

9. Dansie O., 1983: Muntjac. [In: "Muntjac and Chinese water deer"]. British Deer Society: 3-24. Warminster.

10. Ebdon D., 1977: Statistics in geography - a practical approach. Basil Blackwell: $1-195$. Oxford.

11. Goldsmith F. B. \& Harrison C. M., 1976: Description and analysis of vegetation. [In: "Methods in plant ecology," Chapman S. B., Ed.]. Blackwell Sci. Publ.: 85-155. Oxford.

12. Green R. H., 1979: Sampling design and statistical methods for environmental biologists. John Wiley \& Sons: 1-257. New York.

13. Hearney A. W. \& Jennings T. J., 1983: Annual foods of the Red deer (Cervus elaphus) and the Roe deer (Capreolus capreolus) in the east of England. J. Zool., Lond., 201: 565-570.

14. Hofmann R. R., 1982: Morphological classification of sika deer within the comparative system of ruminant feeding types. Deer, 5: 352-353.

15. Jackson J. E., 1974: The feeding ecology of the Fallow deer (Dama dama L.) in the New Forest. Ph. D. Thesis, University of Southampton.

16. Loudon A. S. I., 1983: Habitat and population performance of roe deer. [In: "Some research on deer and its relationship to management"]. British Deer Society: 18-24. Warminster.

17. Marriott F. H. C., 1974: The interpretation of multiple observations. Academic Press: $1-117$. London.

18. Mitchell B., Staines B. W. \& Welch D., 1977: Ecology of red deer. Institute of Terrestrial Ecology: 1-74. Banchory.

19. Noble H., 1903: The birds and other animals of Thetford Warren, Zoologist, 4th series, 7: 155-157.

20. Pickvance T. J. \& Chard J. S. R., 1960: Feral muntjac deer (Muntiacus spp.) in the West Midlands, with special reference to Warwickshire. Proc. Birmingham nat. Hist. phil. Soc., 19: 1-8.

21. Shimwell D. W., 1971: The description and classification of vegetation. Sidgwick \& Jackson: $1-322$. London.

22. Soper E., 1969: Muntjac. Longmans: 1-142. London.

23. Szukiel E., 1981: Food preferences of deer in relation to winter fodder including woody plants. Acta theriol., 26: 319-330.

24. Taylor W. L., 1948: The distribution of wild deer in England and Wales. J. Anim. Ecol., 17: 151-154.

25. Whitehead G. K., 1972: Deer of the world. Constable \& Co: 1-194. London.

26. Whitehead G. K., 1980: Hunting and stalking deer in Britain through the ages. B. T. Batsford: 1-304. London.

27. Williams B. K., 1983: Some observations on the use of discriminant analysis in ecology. Ecology, 64: 1283-1291.

Accepted, February 15, 1985, 
Norma G. CHAPMAN, Kathie CLAYDON, Mick CLAYDON i Stephen HARRIS ROZMIESZCZENIE I WYBIORCZOSC SRODOWISKOWA MUNDŻAKA

I INNYCH JELENIOWATYCH W LESIE IGLASTYM

\section{Streszczenie}

Badania prowadzono na obszarze 2360 ha (King's Forest) lasu, głównie iglastego, w Suffolk (Anglia). Rejestrowano tam występowanie czterech gatunków jeleniowatych, poprzez stwierdzenie ich miejsca przebywania, w każdym z 228 oddziałów (Tabela 1, Ryc. 1). Rozmieszczenie to łączono z właściwościami różniącymi poszczególne oddziały lasu.

Mundżak - Muntiacus reevesi (Ogilby, 1839) preferowal środowiska o różnym typie wegetacji, także w odniesieniu do runa. Jego obecność była jednak istotnie zależna od występowania malin i jeżyn w warstwie krzewów, oraz od ilości starych, owocujących drzew liściastych z następujących jednostek systematycznych: Quercus sp., Fagus sylvatica, Ulmus spp., Castanea sativa, Fraxinus sp. (Ryc. 2).

Sarny występowały na całym badanym obszarze, zatem nie wykazywały wybiórczości środowiskowej (Ryc. 2). Daniele wybierały starodrzew, szczególnie ten w którym udzial Pinus silvestris był duży, natomiast unikały terenów porosłych przez Pinus nigra (Tabela 2, Ryc. 3). Podobnym rozmieszczeniem cechują się jelenie, które również unikały terenów porośniętych sosną czarną oraz obszarów o zróżnicowanym typie drzewostanu, a preferowały te, na których występuje w dużych ilościach $P$. silvestris (Tabela 2, Ryc. 4). Analiza dyskryminacyjna, oparta głównie na istotności różnic między badanymi środowiskami, sprawdza użyteczność stosowanej metody do tlumaczenia ogólnego rozmieszczenia mundżaka w King's Forest (Ryc. 5). 